\title{
PENERAPAN STRATEGI TUTOR SEBAYA DALAM MENINGKATKAN MOTIVASI BELAJAR MATEMATIKA
}

\author{
Ratri Candra Hastari \\ Prodi Pendidikan Matematika STKIP PGRI TULUNGAGUNG \\ E-mail: ratricandrahastari@gmail.com
}

\begin{abstract}
Abstrak
Tujuan dari kegiatan pengabdian pada masyarakat ini adalah: 1)sebagai karya yang tidak dipublikasikan hasil dari pengembangan penelitian internal dan 2) sebagai acuan dalam penerapan metode maupun penerapan strategi pembelajaran di dalam kelas oleh pendidik. Dengan melaksanakan kegiatan ini, manfaat yang dapat dipetik oleh beberapa pihak, antara lain:1) bagi guru matematika, memberikan masukan yang berharga berupa pengetahuan dan keterampilan praktis bagi guru-guru matematika dalam rangka mengupayakan memaksimalkan penerapan strategi tutor sebaya di kelas dalam meningkatkan motivasi hasil belajar dan sebagai masukan kepada guru-guru tentang alternatif pembelajaran yang dapat digunakan dalam pembelajaran dan 2) bagi calon guru atau calon pendidik, sebagai masukan kepada mahasiswa calon pendidik tentang alternatif pembelajaran tutor sebaya yang dapat digunakan dalam pembelajaran.
\end{abstract}

Kata Kunci : tutor sebaya, motivasi, belajar matematika.

\section{PENDAHULUAN}

Ruseno (2010: 95) mengatakan bahwa pembelajaran dengan metode tutor sebaya memberikan kebebasan kepada siswa yang menjadi tutor untuk mengembangkan metode dalam menjelaskan materi kepada teman- temannya. Namun demikian, mereka juga diberi tanggung jawab oleh dosen agar bisa menjelaskan materi pelajaran pada teman (tutee) yang masih belum paham, sehingga dalam pelaksanaannya tutor bisa lebih leluasa dalam menyampaikan materi sesuai dengan keinginan tutee mengikuti kegiatan pembelajaran lebih efektif, karena mahasiswa atau siswa akan lebih leluasa untuk mengatur waktu pembelajaran, tujuan-tujuan belajar dan target penguasaan materi yang diharapkan.

Hasil penelitian yang dilakukan oleh Ruseno(2010) menyimpulkan bahwa pembelajaran melalui tutor teman sebaya efektif meningkatkan belajar berdasar regulasi-diri(adalah kemampuan untuk mengontrol perilaku sendiri) pada mahasiswa. Metode pembelajaran tutor teman sebaya terbukti memberikan kontribusi munculnya perilaku belajar berdasar regulasi-diri pada mahasiswa. Berdasarkan temuan penelitian ini, peneliti menyarankan kepada pengajar di perguruan tinggi memfasilitasi model pembelajaran yang mampu meningkatkan regulasi mahasiswa dalam belajarnya, yaitu melalui metode pembelajaran tutor teman sebaya. Metode pembelajaran tutor teman sebaya ini akan meningkatkan tingkat pemahaman mahasiswa terhadap tugas belajar yang diberikan. Hal ini terlihat dari waktu belajar yang digunakan pada kelompok perlakuan. Mereka selesai tepat waktu dan penyelesaian tugas lebih cepat dibandingkan kelompok kontrol dengan model pembelajaran konvensional.

Menurut Apriyani (2013: 6) salah satu inovasi pembelajaran yang dapat meningkatkan kerjasama siswa yaitu model pembelajaran Tutor Sebaya. Model pembelajaran Tutor Sebaya merupakan salah satu pembelajaran kooperatif. Menurut Slavin (dalam Apriyani, 2013: 7) pembelajaran kooperatif adalah suatu model pembelajaran dimana siswa belajar dan bekerja dalam kelompok-kelompok kecil secara kolaboratif yang anggotanya 4-6 orang dengan struktuk kelompok heterogen. Tahaptahap model pembelajaran Tutor Sebaya yaitu: 1) siswa dibentuk dalam kelompok secara heterogen, 2) siswa diberikan bahan ajar dan lembar kegiatan untuk didiskusikan setiap kelompok, 3) siswa diberi waktu yang cukup untuk berdiskusi materi dan soal yang diberikan guru, 4) perwakilan dari setiap kelompok diminta mempresentasikan hasil diskusi di depan kelas, 5) siswa diberi post test untuk mengetahui pemahaman dari hasil diskusi, dan 6) siswa dan guru menyimpulkan bersamasama. 
Model pembelajaran tutor sebaya merupakan (peer teaching) salah satu alternatif yang dapat diterapkan kepada siswa atau mahasiswa dalam proses belajar mengajar, khususnya untuk mata kuliah di program studi matematika. Siswa atau mahasiswa cenderung merasa takut dan tidak berani untuk bertanya atau mengeluarkan pendapatnya kepada guru, tetapi siswa akan lebih suka dan berani bertanya atau mengeluarkan pendapatnya tentang materi pelajaran kepada temannya atau siswa lain. Sehingga dengan diterapkannya model pembelajaran tutor sebaya ini diharapkan dapat membantu siswa untuk dapat menerima materi pelajaran. Menurut Alwi (2009) ada pengaruh yang signifikan dari metode tutor teman sebaya terhadap motivasi belajar matematika siswa SMA. Hal ini berarti bahwa penerapan metode pembelajaran tutor sebaya akan meningkatkan motivasi belajar matematika siswa SMA.

Dalam kaitannya dengan bidang studi matematika, motivasi belajar matematika adalah keseluruhan daya penggerak dalam diri siswa yang menimbulkan kegiatan belajar, sehingga tujuan belajar yang dikehendaki siswa berupa pencapaian prestasi belajar yang tinggi dalam bidang studi matematika dapat tercapai. Motivasi merupakan dorongan, hasrat, kebutuhan seseorang untuk melakukan aktivitas tertentu dalam hal ini motivasi untuk belajar. Motivasi pada hakikatnya merupakan faktor rangsangan yang terjadi baik secara internal maupun eksternal yang datang dari luar, yang selanjutnya akan menyebabkan manusia mengalami rangsangan atau dorongan dan kemudian bersikap dan berperilaku. Hal ini berarti motivasi adalah merupakan seperangkat daya ataupun kekuatan dalam jiwa yang harus diterjemahkan oleh seseorang kedalam bentuk perilaku yang sesuai dengan tuntutan yang timbul dari dalam (internal) dirinya maupun oleh dorongan dan lingkungannya (eksternal). Menurut Maria(2015) dapat dijelaskan bahwa motivasi belajar adalah merupakan motivasi perubahan energy, rasa, dan rangsangan atas tujuan dalam melakukan belajar untuk siswa atau peserta didik.

\section{METODE KEGIATAN}

Metode yang dipilih dalam melaksanakan kegiatan pengabdian pada masyarakat ini adalah pembuatan karya yang tidak dipublikasikan hasil dari penelitian internal dan hasil dari kajian pustaka hasil penelitian lainnya. Judul pengabdian ini adalah penerapan strategi pembelajaran tutor sebaya untuk meningkatkan motivasi belajar matematika. Langkah-langkah kegiatan atau prosedur pelaksanaan kegiatan pengabdian kepada masyarakat yang akan ditempuh adalah sebagai berikut:

a) Pembuatan Proposal untuk diupload dan direview oleh reviewer.

b) Menunggu hasil revisi dari reviewer

c) Merevisi proposal

d) Proposal disetujui dilanjutkan untuk pelaksanaan kegiatan

e) Produk yang dihasilkan pada pengabdian masyarakat ini berupa artikel maupun prosiding yang bermanfaat untuk beberapa pihak antara lain: 1. Bagi mahasiswa Mendapatkan pengalaman dan pengetahuan yang nantinya dapat menjadi anggota masyarakat yang memiliki kemampuan akademis dan/atau profesional yang dapat menerapkan, mengembangkan dan meyebarluaskan ilmu pengetahuan, teknologi dan/ atau kesenian serta memperkaya budaya nasional, 2. Bagi Lembaga/institusi, dan 3. Bagi dosen pendamping

\section{Kerangka Metode Pelaksanaan}

Adapun tahapan dari metode pelaksanaan kegiatan pengabdian kepada masyarakat ini mengikuti alur seperti yang digambarkan pada bagan di bawah ini:

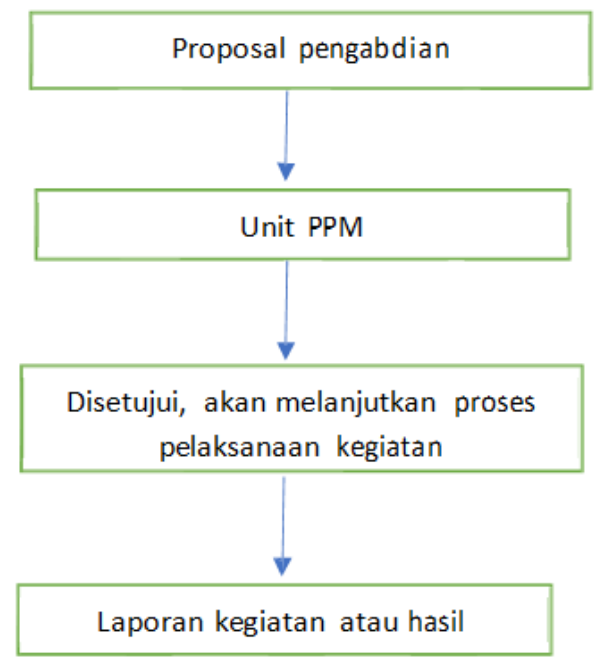

\section{HASIL DAN PEMBAHASAN}

Rencana pelaksanaan pembelajaran pada penerapan strategi tutor sebaya dalam meningkatkan motivasi belajar matematika adalah sebagai berikut: 


\section{RENCANA PEL AKSANAAN PEMGELAJARAN}

(RPP)

\begin{tabular}{|c|c|}
\hline Setuar Pendidikan & SMA \\
\hline Mata Pelsjeran & : Matemetika Wajib \\
\hline $\begin{array}{l}\text { Kelas / Sementer } \\
\text { Tahun Pelajaran }\end{array}$ & $\begin{array}{l}\mathrm{xd} / \mathrm{II} \\
2018 / 2019\end{array}$ \\
\hline Materi Pokok & Limit Fungai Aljabaz \\
\hline Alokani Wakta & $2 \times 45$ Menit \\
\hline
\end{tabular}

A. Kompetensi Inti

$\mathrm{K} \perp 1$

: Menghoyati den mentumellan ajeran agama yang dianutrya.

KI 2 : Mesphayati den mebpamalkas perilake jujur, disiplin, tangtrang jawab, pedult ( gotong royong. kerjastris, toleramsi, damai ). santhin, responsif dan prouktif dm mecunjuklan silorp sebagai bagian deri solua atas becbagzi permeialehen dalam beriateraicsi secara efektif dengan lingkungan sosial dan alem serta dalam menempetkan diri sebagai cerminan bangas dolam pergaulen cunis

KI 3 : Memohrmi, meserzpican, meaganalisis perzetshuan fektual, kocseptual, procedural berdasarken rasa isgin tahunya testang Ilmu pengetahusn, tekologi. seci, bujaya, dan bumaniora dengan wawasen kemantsioen kobangsan, kenegaraan, den peradaban terkait peryebeb fenomena dan kejadian, serta menerapkan pengetahum prosedural poda bidmg kajian yang spesifik sesuai dengan bakat dan minatrya untak memecahican masolsh

KI 4

: Aecgolah, mabaler, dan meayaji dalem ranah kceikret den ranoh

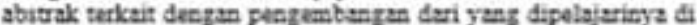
seicolah secara mandiri, dm mampu mengrumvass metoda sesuai kaidak keilmuan.

B. Koxpetensu Dasar dan Indikator Pencapaian Korupetensi

\begin{tabular}{|c|c|c|}
\hline & KD Ketrampilan & IPKKetrampilin \\
\hline 4.7 & $\begin{array}{l}\text { Menyelesaikan maualah yang } \\
\text { berkatan deagan limit fungui } \\
\text { aljabur }\end{array}$ & 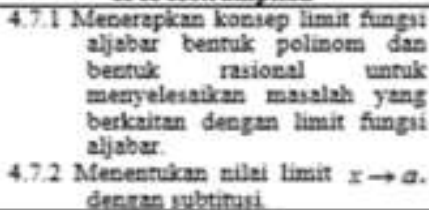 \\
\hline
\end{tabular}

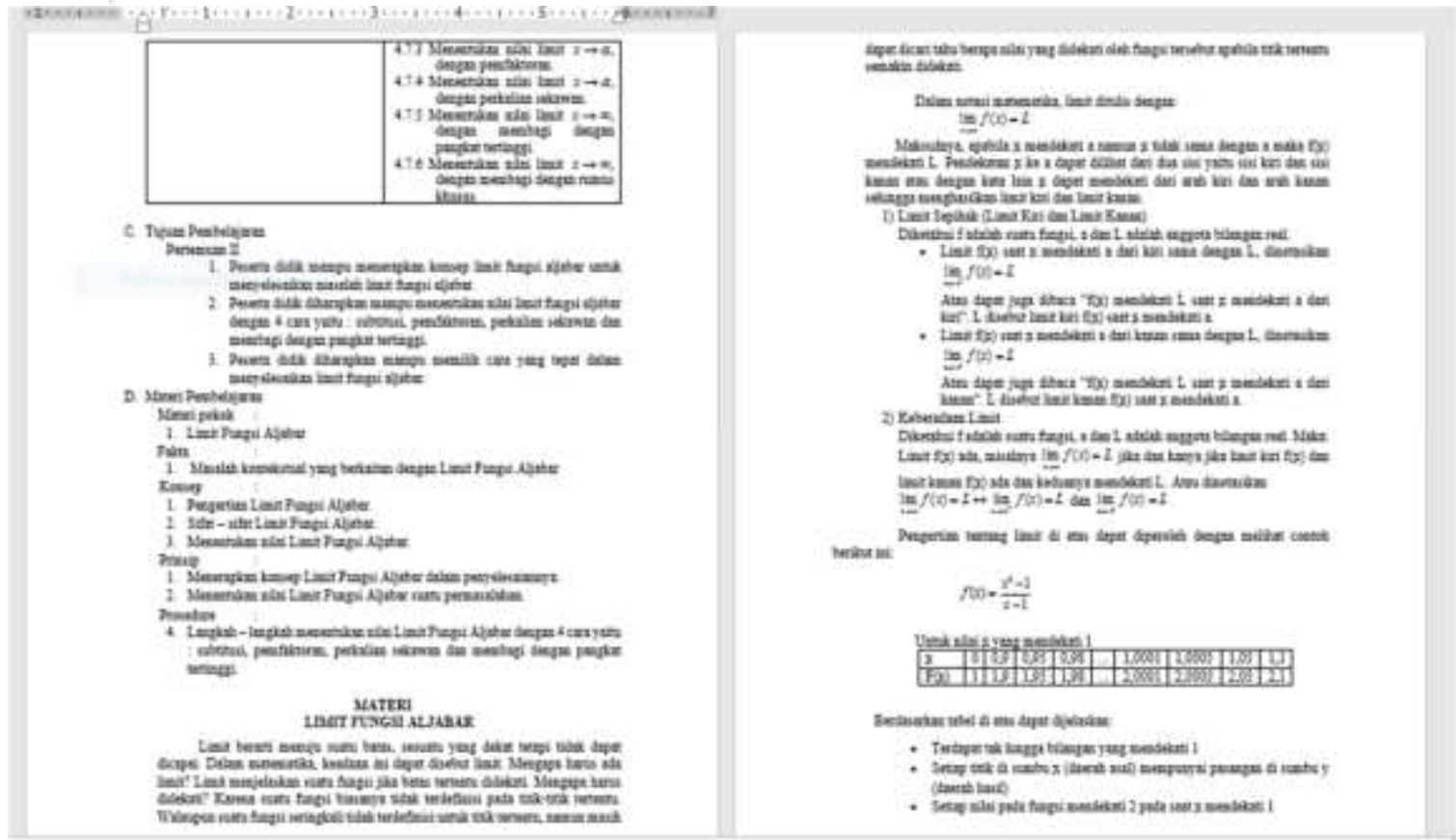



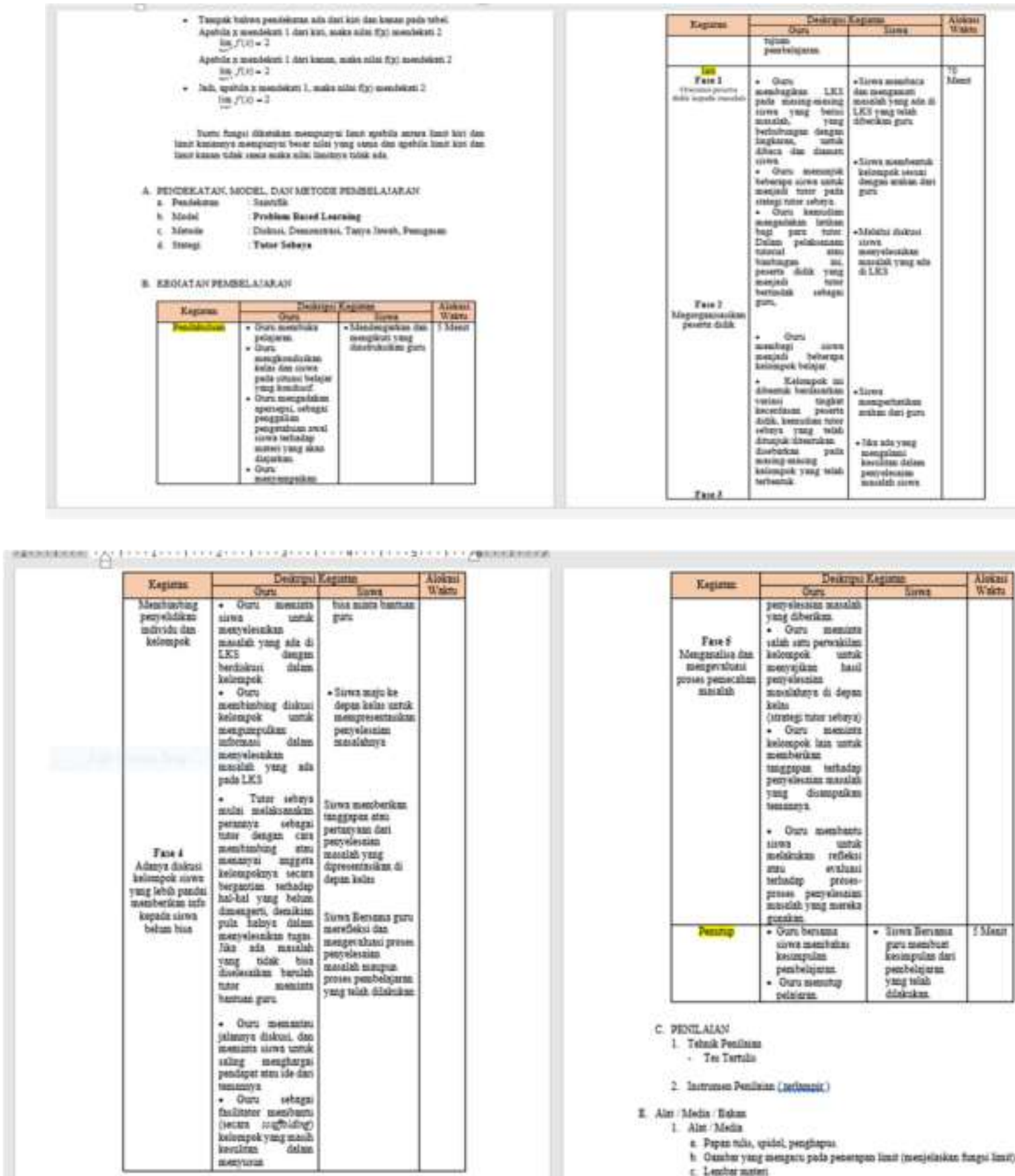

\section{KESIMPULAN}

Berdasarkan uraian pada bab sebelumnya, dapat disimpulkan sebagai berikut:

1. RPP strategi pembelajaran tutor sebaya bisa digunakan sebagai contoh mahasiswa pada mata kuliah

2. Melalui startegi tutor sebaya dengan adanya diskusi kelompok dan tutor mambantu siswa mempunyai sikap bertanggung jawab, saling menghargai dan menghormati pendapat teman, saling membantu dan bekerjasama sehingga menumbuhkan motivasi dalam kegiatan pembelajaran.

3. Penerapan model tutor sebaya dapat memberikan motivasi dan mendorong peserta didik menjadi aktif dalam proses pembelajaran sehingga peserta didik tidak hanya diam, mencatat, dan mendengarkan ceramah dari guru, melainkan peserta didik akan terlibat secara aktif dalam proses pembelajaran bersama dengan tutor dan anggota lain dalam 
kelompoknya. Tutor sebaya merupakan salah satu strategi pembelajaran untuk membantu memenuhi kebutuhan peserta didik. Rasa saling menghargai dan mengerti dibina diantara peserta didik melalui kerja sama. Tutor sebaya akan merasa bangga atas perannya dan juga belajar dari pengalamannya. Hal ini membantu memperkuat apa yang telah dipelajari dan diperoleh atas tanggung jawab yang dibebankan kepadanya. Ketika mereka belajar dengan "tutor sebaya" peserta didik juga mengembangkan kemampuan yang lebih baik untuk mendengarkan, berkonsentrasi, dan memahami apa yang dipelajari dengan cara yang bermakna. Penjelasan tutor sebaya kepada temannya lebih memungkinkan berhasil dibanding guru, dikarenakan, peserta didik pada Kelas Tutor sebaya melihat masalah dengan cara yang berbeda dibandingkan orang dewasa dan mereka menggunakan bahasa yang lebih akrab. Pengajaran tutor sebaya yang dalam pelaksanaannya mampu membuat suasana pembelajaran yang menarik dan menyenangkan ketika peserta didik mempelajari materi. Karena melalui model ini peserta didik bisa berdialog dan berinteraksi dengan sesama peserta didik secara terbuka dan interaktif dibawah bimbingan guru sehingga peserta didik terpacu untuk menguasai bahan ajar yang disajikan. Peran guru dalam hal ini hanyalah sebagai fasilitator dan pembimbing terbatas. Artinya, guru hanya melakukan intervensi ketika betulbetul diperlukan oleh peserta didik. Kelebihan model tutor sebaya dalam penerapannya, bahwa peserta didik diajar untuk mandiri, dewasa dan punya rasa setia kawan yang tinggi.

\section{REFERENSI}

Arjanggi, Ruseno dan Siprihatin, Titin. Desember 2010. Metode Pembelajaran Tutor Teman Sebaya Meningkatkan Hasil Belajar Berdasar Regulasi-Diri. Makara, Sosial Humaniora, Vol. 14, No.2, Desember 2010: 9197.

Apriyani, Dewi dan Harta, Idris. 2012. Upaya Meningkatkan Kerjasama Siswa Dalam Pembelajaran Matematika Melalui Model Pembelajaran Tutor Sebaya. http://eprints.ums.ac.id.

Cleopatra, Maria. 2015. Pengaruh Gaya Hidup Dan Motivasi Belajar Terhadap Prestasi Belajar Matematika. Jurnal Formatif 5(2): 168-181, 2015 ISSN: 2088-351X.

Hayati, Zahral. 2013. Pengaruh Metode Diskusi Kelompok Tutor Sebaya Terhadap Aktivitas Dan Hasil Belajar Mata Pelajaran Biologi Di SMA Srijaya Negara Palembang. Academia.edu

Muhammad Muhib, Alwi. 2009. Pengaruh metode tutor sebaya terhadap motivasi dan prestasi belajar matematika siswa SMA. http://etd.repository.ugm.ac.id.

Sholi, Niken. 2015. Penerapan Model Tutor Sebaya pada Mata Pelajaran Bahasa Inggris Reported Speech terhadap Hasil Belajar Peserta didik MAN Kota Probolinggo. ejournal.umm.ac.id. Volume 1, Nomor 1, Januari 2015;126-132 